\title{
Media Massa dalam Situasi Konflik: dari Bandwagon Effect Sampai Peace Narrative
}

\author{
A. Ranggabumi Nuswantoro \\ Mahasiswa Pascasarjana Ilmu Komunikasi UGM, mengajar di Fakultas Ilmu \\ Sosial dan Ilmu Politik Universitas Atma Jaya Yogyakarta
}

\begin{abstract}
Abstrak
Konflik terjadi antara dua pihak atau lebih yang memiliki kepentingan berbeda. Media berhubungan dengan konflik. Kemampuan media mempengaruhi opini publik merupakan unsur terbesar dalam hubungan antara media dengan konflik. Media dalam konteks ini bisa menjadi pihak yang menyulut terjadinya konflik, tetapi bisa juga berperan sebagai resolutor konflik. Media sebagai provokator ketika berperan menjadi kepanjangan tangan salah satu pihak yang berkonflik, sedangkan menjadi pendamai konflik ketika memperlihatkan kenetralan dan informasi yang cenderung damai (peace narrative). Harus dilakukan kajian teoritis dan penelusuran fakta-fakta empiris mengenai hal ini, untuk memperjelas posisi, kedudukan, dan peran media dalam situasi konflik. Hasil yang didapat dapat digunakan pula untuk melihat sejauh mana media berkontribusi dalam menciptakan kondisi ruang publik dan demokratis deliberatif. Terhadap hal ini, pilihan untuk setia kepada jurnalisme menjadi pilihan yang paling tepat bagi media dalam usaha menjaga posisinya sebagai agen demokrasi di masyarakat.
\end{abstract}

Kata kunci: konflik, peran media, resolusi konflik, demokrasi.

\begin{abstract}
Conflict occurs between two or more parties with different interests. Media related to conflict. The ability of the media to influence public opinion is the biggest element in the relationship between media with conflict. The media in this context can be a party that sparked the conflict but could also act as resolutor conflict. Media as a provocateur when play became an arm of one of the conflicting parties, while a conciliator conflict when showing neutrality and information that tends to peace (peace narrative). And theoretical studies should be conducted searches empirical facts on this subject, to clarify the position, the position and role of media in conflict situations. The results can also be used to see the extent to which the media contribute to creating conditions of public space and democratic deliberative. Against this, the choice to stick with journalism be the most appropriate choice for the media in an effort to maintain its position as an agent of democracy in society.
\end{abstract}

Keywords: conflict, role of media, conflict resolution, democracy.

Manusia adalah serigala bagi sesamanya, homo homini lupus, sebagaimana dinyatakan oleh filsuf bernama Plautus (184 SM dalam bukunya Asinaria), manusia saling memangsa, membenci, dan mengalahkan satu sama lain. Bagi filsafat, inilah akar terjadinya konflik antar manusia. Bahwa manusia memiliki dua kecenderungan sekaligus, yakni bekerja sama dengan orang lain atau bermusuhan dengan orang lain. Situasi dan kondisi hiduplah yang kemudian mengarahkan tindakan manusia, apakah menjadi kawan atau serigala bagi sesamanya. 
Dalam tingkatan yang lebih kompleks, konflik antarmanusia tidak hanya terjadi antara satu manusia dengan manusia lain, tetapi juga antara satu kelompok dengan kelompok lain. Konflik terbuka akhirnya muncul. Substansi konflik tidak hanya menyangkut masalah pribadi, tetapi juga menyangkut perbedaan kepentingan kekuasaan, perebutan lahan ekonomi, sengketa lahan, persinggungan agama, sampai selisih paham politik. Sampai di sini perlu dimunculkan pertanyaan kritis: mengapa eskalasi konflik bisa meningkat dan meluas? Bagaimana menjelaskan sebuah konflik bisa terjadi dalam skala yang sangat besar, melibatkan orang banyak, dan memakan korban yang tidak sedikit?

Sebagaimana muncul dalam penelitian-penelitian mengenai konflik, kebanyakan konflik terjadi karena kesalahpahaman. Dua belah pihak -dalam kasus tertentu pihak yang terlibat lebih dari dua- memiliki pemahaman yang berbeda akan hal/topik yang sedang dipersoalkan. Adapun perbedaan terjadi karena ada komunikasi yang tidak lancar di antara pihak-pihak tersebut. Ini berarti ada sebuah pesan yang dimaknai berbeda antara komunikator (penyampai pesan) dengan komunikan (penerima pesan). Bisa jadi pesannya tidak jelas sehingga interpretasi tidak berjalan dengan semestinya. Namun bisa juga telah terjadi prasangka terlebih dulu di orang yang menerima pesan sehingga posisi pesan tidak lagi netral dan menjadi alat untuk memupuk kecurigaan lebih lanjut. Pastinya, komunikasi menjadi faktor penting dalam konflik, baik sebagai pemicu maupun pereda konflik.

Media massa sebagai alat komunikasi juga berperan dalam konflik. Sebagai produsen sekaligus distributor pesan, media memiliki kepentingan pribadi (institusional) selain kepentingannya untuk menjadi pihak yang berfungsi menghibur, menginformasikan sesuatu, mengontrol kekuasaan, dan untuk mendidik. Kepentingan institusional media terkadang menimbulkan konflik di beberapa daerah. Penyebabnya macammacam, mulaidaripemberitaanyangtidak berimbang hingga konten media yang cenderung menumbuhsuburkan benihbenih konflik (prasangka, stereotipe, dan sebagainya). Lebih lanjut bisa dijelaskan bahwa terdapat konsep-konsep yang menunjukkan dengan jelas peran media di dalam konflik, baik yang memicu konflik maupun yang meredakan konflik. Kepemilikan media, bandwagon effect, bahasa media, dan infection merupakan konsep media yang menjadikan dirinya sebagai pemicu konflik. Sedangkan peace narrative, media center, dan melek literasi adalah konsep media sebagai pereda dan agen resolusi konflik. Tulisan ini akan membahas berbagai macam konsep ini, berbagai hal yang melingkupinya, baik dari aspek teori maupun praktiknya di Indonesia.

\section{Konflik dan Problem Komunikasi}

Problem komunikasi dan pengaruhnya terhadap konflik menjadi kajian yang menarik, seiring dengan berkembangnya kajian-kajian konflik, studi perdamaian, dan sebagainya. Kajian ini menempatkan komunikasi sebagai faktor pemicu konflik, yakni macetnya kesepahaman antara satu pihak dengan pihak yang lain. Selain itu akses terhadap sarana komunikasi yang terbatas juga dapat disalahgunakan menjadi pemicu konflik. Seperti yang terjadi di Ambon beberapa tahun silam. Akses informasi yang terbatas mengenai suatu peristiwa telah dimanfaatkan oleh provokator untuk menyebarkan informasi sesat. Akibatnya 
warga Ambon kehilangan kepercayaan satu sama lain dan terpecah menjadi dua bagian besar, yakni kelompok Islam dan kelompok Kristen. Informasi sesat tersebut hadir lewat SMS (Short Message System), selebaran, dan tulisan-tulisan di website (Baowollo, 2012).

Kenyataan tersebut senada dengan pemikiran Alvin Toffler, bahwa di dunia modern informasi telah menjadi komoditas penting dalam usaha memenangkan kepentingan seseorang, suatu kelompok, maupun institusi. Jika dikelola dengan salah maka informasi bisa menjadi pemicu perselisihan antara satu pihak dengan pihak yang lain.

Bagi studi konflik, komunikasi menjadi unsur penting dalam sebuah konflik. Pruitt dan Rubin (2004) menyatakan bahwa konflik berarti persepsi mengenai perbedaan kepentingan (perceived divergen of interest), atau suatu kepercayaan bahwa aspirasi pihak-pihak yang berkonflik tidak dapat dicapai secara simultan. Persepsi pada mulanya timbul secara personal pada orangorang tertentu -mengenai hal tertentu pula- sebagai efek dari komunikasi yang telah terjadi. Persepsi tersebut kemudian berkembang menjadi opini yang melibatkan lebih banyak orang. Pada titik ini muncul potensi konflik kelompok ketika ditemukan opini berbeda di kelompok lain. Media massa turut berperan mendorong terjadinya konflik ketika kedua opini yang berbeda diangkat di media massa dan menjadi opini publik. Apalagi ketika media memberikan pembenaran yang berat sebelah atas opini yang ada. Potensi konflik yang tadinya bersifat laten menjadi terbuka. Media massa tidak dalam posisi netral dan memberikan ruang yang sama bagi kedua belah pihak, tetapi malah berpihak pada salah satu opini dan menghakimi opini lainnya.

Media massa yang tidak berimbang seperti ini dapat kita jumpai di konflik Maluku, di mana ditemukan adanya perbedaan mendasar antara media Islam dengan media Kristen dalam liputan konflik. Penelitian yang dilakukan oleh Agus Sudibyo, Ibnu Hamad, dan Muhammad Qodari (ketiganya dari Institut Studi Arus Informasi) pada 2001 menunjukkan bahwa media Islam lebih berani memberikan evaluasi-evaluasi yang mensiratkan prasangka negatif tentang kelompok-kelompok Kristen. Sebaliknya, media Kristen sangat berhatihati dalam memberitakan kasus SARA dan cenderung menghindari penilaian langsung terhadap kelompok Islam maupun kelompok Kristen.

Ada opini negatif terhadap kelompok Kristen yang terus-menerus dibangun oleh media Islam (Media Dakwah dan Republika), baik lewat penggunaan istilah-istilah kunci yang bersifat konotatif, metafor dan hiperbola, maupun foto-foto visual yang digunakan untuk merekonstruksi fakta kerusuhan. Sebaliknya, media Kristen (Suara Pembaruan) terkadang membela opini kelompok Kristen di Maluku. Walaupun hal itu dilakukan dengan cara yang sangat berhati-hati seperti menggunakan bahasa yang implisit dan eufemistik (Sudibyo dkk, 2001: 176).

Penggiringan opini oleh media seperti ini semakin memperuncing konflik. Seolah-olah membenarkan opini orang-per-orang yang berprasangka buruk terhadap pihak lain. Media tidak memposisikan diri sebagai saluran komunikasi yang netral, melainkan menjadi pembentuk persepsi dan opini tentang suatu hal yang cenderung buruk serta negatif. 
Lebih lanjut Pruitt dan Rubin (2004) juga menyatakan pemikirannya bahwa komunikasi telah mendorong kepentingan laten suatu kelompok muncul ke permukaan. Dikatakan olehnya ketika beberapa orang dengan kepentingan laten (tidak disadari) yang sama saling bercakap-cakap, maka kepentingan laten mereka seringkali muncul ke kesadaran. Setelah merasa yakin dengan pendirian masingmasing, mereka mungkin akan mulai mengembangkan aspirasi baru, yang dapat mengarah ke konflik dengan orang lain yang kepentingannya bertentangan dengan aspirasi terebut. Konflik semacam itu terutama akan muncul bila mereka mulai mengidentifikasi diri sebagai kelompok yang terpisah dari kelompok lainnya. Aspirasi yang sama tersebut kemudian berubah menjadi norma kelompok, dan kepemilikan aspirasi tersebut menjadi manifestasi kesetiaan terhadap kelompok. Hasilnya disebut sebagai struggle group. Struggle group inilah yang bertindak sebagai inisiatorinisiator konflik. Mereka cenderung mencari dan mendekati pihak-pihak yang berseberangan aspirasinya, bukan untuk menyamakan persepsi atas aspirasi tetapi justru berkonflik.

Dahrendorf (dikutip oleh Pruitt dan Rubin, 2004:34-35) menyebutkan tiga kondisi yang mendukung kemunculan struggle group, yang seringkali menjadi pendorong terjadinya konflik, yaitu:

(1) komunikasi terus-menerus di antara orang-orang senasib;

(2) adanya seorang pemimpin yang membantu mengartikulasikan ideologi, mengorganisasikan kelompok, dan memformulasikan rencana untuk melakukan tindakan kelompok;
(3) legitimasi kelompok di mata komunitas yang lebih luas meningkat.

Catatan yang perlu diberikan dalam teori struggle group ini adalah mengenai tipe komunikasi yang berlangsung. Tipe komunikasi yang memungkinkan munculnya kepentingan laten adalah tipe interpretatif dan tipe evaluatif ${ }^{1}$. Komunikasi tipe interpretatif adalah tipe komunikasi di mana pesan yang dipertukarkan merupakan pesan sekunder yang sudah dimuati unsurunsur interpretasi komunikator. Artinya pesan tidak lagi murni dan bebas nilai. Sedangkan komunikasi tipe evaluatif/ judgemental adalah tipe komunikasi dimana komunikator sudah memiliki prasangka terhadap pihak lain yang menjadi topik pembicaraan. Akibatnya pesan-pesan yang terlontar selalu negatif.

Selanjutnya, arus informasi yang tidaklancar telah menyebabkan terjadinya prasangka. Prasangka adalah suatu sikap (yang biasanya negatif) terhadap para anggota kelompok tertentu, yang sematamata didasarkan keanggotaannya di kelompok tersebut. Dengan kata lain, seseorang yang mempunyai prasangka terhadap kelompok sosial tertentu cenderung menilai anggota-anggotanya dengan cara tertentu (biasanya secara negatif) hanya karena mereka merupakan bagian dari kelompok tersebut (Baron \& Byrne, 1997). Informasi yang terbatas dan mentah menyebabkan orang mengambil penilaian dini terhadap orang lain. Dalam hal ini media berperan cukup penting. Dikatakan oleh Baron dan Byrne, media massa berperan dalam perkembangan prasangka.

${ }^{1}$ Tipe komunikasi lainnya adalah tipe deskriptif Pada tipe ini komunikator menyampaikan pesan apa adanya, tidak ditambah dan tidak dikurangi. Orang yang melaksanakan tipe ini bicara satu sama lain berbasis data primer. 
Film atau televisi membentuk prasangka. Sebelumnya, para anggota pelbagai minoritas rasial dan etnik sangat jarang diperlihatkan di dalam film atau televisi. Kalaupun muncul di sana, mereka seringkali mendapatkan peran yang berstatus rendah atau peranperan komik. Dengan berulang kali melihat tayangan semacam itu selama bertahun-tahun atau bahkan berdekade-dekade, tidak mengejutkan jika banyak anak kemudian percaya bahwa para anggota kelompok itu pasti inferior. Pada tahapan lanjut prasangka akan berubah menjadi tindakan, yakni diskriminasi. Pada titik ini konflik rentan terjadi, sebab kelompok yang mengalami diskriminasi bakal menolak atau bahkan melawan (Baron \& Byrne, 1997:174).

Beberapa konsep mengenai konflik dan komunikasi di atas menunjukkan bahwa keduanya saling mempengaruhi. Komunikasi yang tidak berjalan sempurna akan menimbulkan konflik. Sebaliknya jika terjadi konflik maka bisa dipastikan komunikasi menjadi runyam. Sebagai bagian dari komunikasi, media massa juga terlibat dalam konflik baik sebagai pemicu maupun pereda. Selanjutnya akan dipaparkan konsep-konsep media massa dalam situasi konflik serta media massa dalam resolusi konflik.

\section{Media Massa dalam Situasi Konflik}

Jika melihat empat fungsi media, yakni to inform, to educate, to control, dan to entertain, sulit rasanya membayangkan media menjadi bagian dari konflik. Namun kajian teoretis dan temuan di lapangan telah menunjukkan hal sebaliknya, bahwa media tidak hanya menjadi bagian dari sebuh konflik, atau berada dalam situasi konflik, melainkan medialah penyebab konflik. Dengan kekuatan modal, tenaga kerja, informasi, dan teknologi yang dimilikinya, media mampu berbuat banyak hal di masyarakat. Baowollo (2012) menyatakan setidaknya ada 4 konsep yang harus diperhatikan ketika membicarakan media dalam situasi konflik: (1) kepemilikan media; (2) bandwagon effect; (3) infection; (4) bahasabahasa media.

\section{II.A. Kepemilikan Media}

Kerja jurnalistik media dipengaruhi banyak hal, salah satu yang paling dominan adalah pemilik media (media owner). James Watson (1998) menyatakan bahwa siapa yang mengontrol proses komunikasi massa niscaya mendapat pengaruh besar dalam konteks sosial yang lebih luas. Efek ini nampaknya diminati oleh pemilik media, sehingga kepentingan ekonomi politik mereka acapkali harus masuk dalam ranah kerja jurnalistik yang dilakukan oleh awak media. Das Freedman (2008) memberikan tesis menarik mengenai hal ini: sistem media dibentuk oleh pemilik media dengan tujuan ekonomi politik tertentu, dengan nuansa-nuansa teknologi, ekonomi, dan sosial di dalamnya. Maka pemilik media memang memiliki kepentingan ekonomi politik dari media yang dimilikinya.

Perjumpaan pemilik media dengan jurnalisme menjadi perjumpaan yang menarik sebab kedua-duanya memiliki kepentingan atas media.

Dalam studi ekonomi politik media, kita perlu melihat wartawan sebagai pihak yang menyiapkan produk informasi kepada audiens. Kita juga perlu melihat bagaimana interaksi wartawan dengan pemilik media dalam kaitannya dengan kinerja jurnalistik. Sebab jika seorang wartawan berpolitik, atau dipengaruhi pemilik media 
untuk berpolitik, maka dia akan mempunyai sikap berbeda terhadap informasi. Sikap yang berbeda inilah awal dari masalah konflik, yakni ketika informasi diperlakukan berbeda oleh wartawan sebagai akibat dari kebijakan pemilik media (Fred Inglis, 1990: 120)

Salah satu contoh bagaimana kebijakan pemilik media menimbulkan konflik adalah kebijakan salah satu kelompok media besar dalam meliput konflik Maluku². Penelitian Eriyanto menunjukkan bahwa konflik di Maluku ternyata tidak berdiri sendiri. Media ikut menjadi bagian di dalamnya, dan bahkan memperkeruh suasana. Akhirnya yang terjadi bukan hanya konflik antara kelompok Islam dan Kristen, tapi juga persaingan antarmedia yang berbasiskan sentimen agama, tepatnya Suara Maluku dan Ambon Ekspres (Eriyanto, 2005). Suara Maluku dianggap mewakili suara Kristen sedangkan Ambon Ekspres mewakili suara Islam. Persaingan tersebut terjadi akibat kebijakan kelompok Jawa Pos dalam membentuk dua koran berbeda agama di Ambon. Kedua media tersebut dinilai ikut memperumit konflik di Maluku sebab masing-masing menampilkan kebenaran versi agamanya.

Misalnya dalam kasus Toma Jaya. Peristiwanya berlangsung pada 27 Juli 2001. Saat itu kapal motor Toma Jaya membawa 11 penumpang dari Asilulu menuju Ambon. Asilulu wilayah di Maluku Tengah yang mayoritas penduduknya beragama Islam. Seluruh penumpang dalam kapal tersebut beragama Islam. Naas bagi Toma Jaya, sebelum sampai di Ambon kapal tersebut diterjang badai dan terpaksa menepi ke pesisir pantai di desa

${ }^{2}$ Kelompok Jawa Pos adalah induk dari Ambon Ekspres dan Suara Maluku.
Liliboy yang mayoritas berpenduduk Kristen. Para penumpang selamat, tapi kisah selamatnya awak kapal tersebut diceritakan secara berbeda-beda. Suara Maluku menuliskan bahwa penumpang selamat berkat kebaikan dan cinta kasih penduduk Kristiani Liliboy. Saat Toma Jaya oleng dan terapung-apung, penduduk Liliboy yang melihat orang berenang dalam gelombang besar segera datang menolong. Sedangkan Ambon Ekspres menuliskan hal berbeda. Saat kapal menepi di pantai desa Liliboy, warga desa justru mengacung-acungkan parang dan golok. Mereka berteriak, kalau kapal menepi, semua penumpang akan dihabisi. Penumpang panik dan meloncat ke laut. Mereka berenang tanpa menyentuh tepi desa Liliboy (Eriyanto, 2005: 259-260). Versi mana yang benar? Yang pasti baik wartawan Ambon Ekspres maupun Suara Maluku tak pernah terjun ke lapangan. Mereka menulis berita hanya dari satu sisi. Walau demikian pemberitaan mereka dipercaya oleh masing-masing pembacanya.

Kebijakan Jawa Pos dalam membuat dua media berbeda di Maluku telah menuai konflik. Jawa Pos hanya memperhatikan kepentingan ekonomi politik pemiliknya saja, tanpa melihat bahwa pemberitaannya memicu konflik lebih luas di Maluku. Hal ini tepat dengan ungkapan klasik yang ditulis Philip Knightley dalam buku The First Casualty: A History of War, Correspondents and Propaganda. Kebenarannya terbukti. Saat perang berkecamuk, keinginan orang untuk membaca meningkat. Orang ingin tahu apa yang terjadi di luar (dikutip Eriyanto, 2005: 261). Tulisan Knightley seolah menggarisbawahi bahwa unsur ekonomi politik media mempengaruhi bagaimana media bersikap dan bertindak. Oplah Ambon Ekspres dan 
Suara Maluku sama-sama meningkat saat konflik. Walau akhirnya Kelompok Jawa Pos menggabungkan mereka namun kebijakannya membuat dua koran berbeda di satu daerah saat konflik telah menimbulkan kerumitan masalah yang berkepanjangan.

\section{II.B. Bandwagon Effect}

Secara teori Bandwagon effect dapat didefinisikan sebagai kecenderungan orang-orang melakukan atau mempercayai sesuatu karena mayoritas orang melakukan atau mempercayai hal itu. Keyakinan umum tersebut, walaupun belum tentu benar, menurut Roger Fisk adalah sebuah strategi yang sangat manjur dalam meyakinkan masyarakat. Insan intelijen biasa menyebutnya sebagai "conditioning", dimana target akan dipengaruhi agar mau berpikir dan berbuat seperti apa yang dikehendaki oleh "handler" tadi.

Media dalam hal ini menjadi pihak yang meyakinkan masyarakat bahwa suatu hal wajar untuk dilakukan, pun bahkan ketika hal tersebut berupa konflik. Seolah-olah ketika menjumpai situasi dimana ada perbedaan dan perselisihan, konflik selalu menjadi jalan keluarnya. Masyarakat di suatu daerah meniru apa yang dilakukan masyarakat di daerah lain lewat media. Media menginspirasi masyarakat untuk melakukan hal sama yang sudah/telah dilakukan oleh masyarakat di daerah lain. Misalnya: media terus-menerus menayangkan berita demo di Jakarta, yang ujungujungnya adalah bentrok dengan aparat keamanan. Hal tersebut akhirnya ditiru oleh masyarakat di daerah lain ketika berdemo. Substansi demo bisa beda tetapi gaya dan pola demo meniru apa yang terjadi di Jakarta, yakni berujung bentrok dengan aparat keamanan.
Atau ketika media menampilkan berita sengketa lahan di suatu daerah, yang berujung bentrok antara pengembang dan warga setempat. Ketika berita semacam ini ditampilkan terus-menerus (dengan substansi berbeda tetapi pola kejadiannya sama yakni bentrok antara pengembang dengan warga setempat) maka akan menginspirasi warga di daerah lain untuk melakukan hal yang sama ketika terjadi sengketa lahan. Demo dan bentrok menjadi jalan keluar dari selisih paham soal lahan.

\section{II.C. Infection}

Teori Infection atau Infeksi di sini sepenuhnya memodifikasi teori infeksi di ilmu kedokteran. Infeksi, menurut ilmu kedokteran, adalah kolonalisasi yang dilakukan oleh spesies asing terhadap organisme inang, dan bersifat pilang membahayakan inang. Organisme penginfeksi, atau patogen, menggunakan sarana yang dimiliki inang untuk dapat memperbanyak diri, yang pada akhirnya merugikan inang. Patogen mengganggu fungsi normal inang dan dapat berakibat pada luka kronik, gangrene, kehilangan organ tubuh, dan bahkan kematian. Respons inang terhadap infeksi disebut peradangan. Secara umum, patogen umumnya dikategorikan sebagai organisme mikroskopik, walaupun sebenarnya definisinya lebih luas, mencakup bakteri, parasit, fungi, virus, prion, dan viroid. Singkatnya, infeksi adalah kondisi sakit dimana bibit penyakit masuk ke dalam tubuh manusia. Penyakit ini menular satu sama lain.

Dengan menggunakan logika yang sama, teori infeksi dalam konteks media dankonflik bisadijelaskan sebagaiberikut: bahwa media membawa pengaruh dari luar -bisa berupa nilai, ideologi, atau hasutan- yang mampu memprovokasi 
masyarakat untuk melakukan tindakan yang berujung pada konflik. Media menulari suatu masyarakat tertentu untuk berkonflik (Baowollo, 2012). Media menumbuhsuburkan kebencian dan prasangka masyarakat akan suatu hal, biasanya terhadap hal-hal yang menyangkut agama, ras, kelompok, serta etnis. Akibatnya masyarakat terporvokasi dan meningkatkan potensi prasangka yang sudah ada menjadi perlakukan diskriminatif, hingga akhirnya berujung konflik terbuka.

Dunia Islam pasca kejadian runtuhnya menara WTC (11 September 2001) mengalami prasangka negatif dari negara-negara barat. Mereka menuduh masyarakat Islam sengaja melakukan penyerangan terbuka untuk mencapai satu dunia Islam yang utuh di muka bumi ini. Prasangka dikonstruksi oleh Amerika Serikat (saat pemerintahan George W. Bush), kemudian disebarluaskan oleh media-media Barat. Akibatnya negaranegara Islam mengalami diskriminasi, termasuk Indonesia. Banyak di antara mereka yang dikenakan travel warning, sehingga kunjungan wisatawan menurun. Selain itu banyak kerja sama tingkat internasional yang ditinjau ulang karena prasangka ini. Bagaimana proyek-proyek pendidikan dan kemanusiaan yang tadinya berjalan lancar menjadi tersendat. Media barat telah memprovokasi masyarakat internasional untuk menaruh prasangka negatif terhadap Islam.

Dalam lingkup yang lebih kecil media di Indonesia juga menyebarluaskan prasangka. Contoh kasusnya ada di Bali. Pasca peristiwa bom Bali, muncul prasangka negatif masyarakat Bali terhadap pendatang terutama mereka yang beragama Islam. Prasangka tersebut bertumbuh semakin subur bukan hanya karena satu per satu orang
Bali membenci pendatang, tetapi karena media lokal terus-menerus menampilkan berita negatif mengenai pendatang (Islam) sehingga menginfeksi prasangka yang sudah ada sebelumnya. Salah satu media yang paling kelihatan adalah Bali Post (Burhanuddin, 2008). Bali Post bahkan turut mensponsori gerakan Ajeg Bali, yakni gerakan yang mengajak masyarakat Bali untuk berpikir, berkata, dan berbuat bagi kejaegan Bali, khususnya di bidang agama dan budaya. Gerakan ini sebenarnya bertujuan baik, yakni menjaga ada dan budaya asli Bali dari pengaruh-pengaruh luar. Tetapi dalam pelaksanaannya Ajeg Bali kerap disalahgunakan sebagai dasar untuk mendiskriminasikan pendatang.

Dua kasus di atas menunjukkan bahwa media menulari masyarakat untuk berkonflik. Media menumbuhsuburkan kebencian dan prasangka masyarakat akan suatu hal atau kelompok tertentu. Akibatnya, muncul perlakuan diskriminatif yang ujung-ujungnya menyebabkan terjadinya konflik terbuka.

\section{II.D. Bahasa-Bahasa Media}

Bahasa merupakan alat pokok media dalam menyampaikan informasi kepada publik. Istilahnya, bahasa adalah perangkat utama media dalam melakukan konstruksi realitas. Bahasa merupakan alat konseptualisasi dan alat narasi. Begitu pentingnya bahasa, maka tak ada berita, cerita, ataupun ilmu pengetahuan tanpa ada bahasa. Selanjutnya, penggunaan bahasa (simbol) tertentu menentukan format narasi (makna) tertentu (Tuchman, dalam Sudibyo dkk, 2001). Bahasa mengarahkan bagaimana persepsi terbentuk atas realitas yang dimunculkan media, apakah suka, benci, intim, atau dingin. 
Dalam situasi konflik, bahasa media menunjukkan kecenderungan sikap media, apakah membela salah satu pihak yang berkonflik, netral, atau menjadi juru damai atas konflik yang ada. Bahasa media mencerminkan sebuah perspektif berpikir, dengan demikian terlihat pula idealisme media tersebut (Baowollo 2012). Dari idealisme tersebut, media kemudian menentukan kecenderungannya apakah berpihak atau netral. Dalam sub bab ini akan dibahas bagaimana media menyuburkan konflik dari sudut penggunaan bahasanya. Bagaimana ketika idealisme bertemu dengan situasi konflik, realitas seperti apakah yang dikonstruksi oleh media?

Pertama-tama yang harus dilihat adalah latar belakang media tersebut, apakah berafiliasi dengan kelompok besar atau tidak. Kelompok di sini bisa grup media, kelompok politik, atau bahkan negara. Biasanya media yang berafiliasi dengan kelompok tertentu cenderung memiliki kepentingan politik tertentu. Dalam situasi konflik, hal tersebut berbahaya karena ada kecenderungan media menjadi partisan, hanya membela kepentingan kelompoknya saja (Baowollo, 2012). Seperti yang diteliti oleh Eriyanto (2001), terdapat dua media di Maluku yang cenderung tidak netral karena idealisme yang ditanamkan oleh kelompok/grup media seperti itu. Maksudnya, ada skenario dari grup supaya kedua medianya melayani kepentingan masing-masing pihak yang berkonflik. Dalam konteks Maluku, satu media melayani kelompok Islam (Ambon Ekspres) dan media lain melayani kelompok Kristen (Suara Maluku). Di sini yang kemudian menjadi fokus adalah pembahasaan berita yang memperuncing konflik, yang dihasilkan oleh dua media tersebut.
Penelitian yang dilakukan oleh Eriyanto menemukan bahwa pembaca Kristen yang membaca Suara Maluku akan selalu disuguhi berita penyerangan terhadap desa Kristen dan semacamnya. Sebaliknya, warga Islam yang membaca Ambon Ekspres akan disuguhi berita soal serangan terhadap warga Islam atau konspirasi gereja dan RMS. Contohnya, berita peristiwa Wisma Gonsalo, Karang Panjang, pada 12 Juni 2001. Dalam peristiwa tersebut tiga orang meninggal dan puluhan orang luka-luka. Suara Maluku edisi 13 Juni 2001 menulis berita dengan judul "Kopertis Disusupi Perusuh, Teluk Dalam Bergolak, Delapan Meninggal, Puluhan Warga Kristen Terluka". Sementara pada hari yang sama, Ambon Ekspres menulis peristiwa itu dengan tajuk "Teluk Ambon dan Karang Panjang Kembali Berdarah" (Eriyanto, 2005: 259).

Suara Maluku dan Ambon Ekspres adalah contoh media yang menerapkan bahasa tidak netral, atau dalam bahasa Sirikit Syah (2012) bahasa media menampilkan diri dalam konsep "incentive kills". Artinya apa yang ditulis oleh media akhirnya bisa memancing kerusuhan atau konflik lebih lanjut. Bahasa yang ditampilkan oleh Suara Maluku dan Ambon Ekspres mengarahkan pembacanya untuk mempersepsi buruk kelompok-kelompok di luar kategorinya. Pembaca dikonstruksi untuk membenci satu sama lain, terutama membenci mereka yang berada di luar kelompoknya.

\section{Media Massa Dalam Resolusi Konflik}

Resolusi konflik merupakan suatu terminologi ilmiah yang menekankan kebutuhan untuk melihat perdamaian sebagai suatu proses terbuka dan membagi proses penyelesaian konflik dalam beberapa tahap sesuai dengan 
dinamika siklus konflik (Widjajanto, dalam Rozi dkk, 2006). Tahap pertama adalah pengendalian konflik terbuka oleh pihak militer. Kedua, intervensi kemanusiaan dan negoisasi politik. Ketiga, pemusatan upaya untuk mengatasi masalah (problem solving). Keempat, peace building atau melakukan perombakan sosial-budaya yang dapat mengarah pada pembentukan komunitas damai yang langgeng.

Hal yang penting untuk diperhatikan dalam resolusi konflik adalah penghilangan hambatan-hambatan psikologis pada pihak-pihak yang bertikai, seperti prasangka, stereotipe, dan sebagainya. Usaha ini bisa diwujudnyatakan dalam tahapan yang keempat, yakni ketika konflik terbuka sudah usai, intervensi kemanusiaan sudah dilakukan, problem utama sudah diatasi, dan mulai dibangun komunitas damai. Saat seperti ini prasangka-prasangka negatif satu sama lain disingkirkan. Sebagai gantinya dibangun opini yang positif satu sama lain. Media sebagai pengonstruksi realitas memiliki peran penting di tahap ini. Ada tiga hal yang bisa dilakukan media untuk mendorong proses resolusi konflik, yakni melaksanakan peace narrative, membentuk media center, dan menginisiasi gerakan melek literasi.

\section{III.A. Melaksanakan Peace Narrative}

Peace narrative merupakan tulisan naratif, bisa berbentukfeature atau laporan khusus, yang dengan perspektif tertentu menampilkan kebaikan dan kedamaian dalam suatu konflik (Baowollo, 2012). Dalam peace narrative, positive capital atau peace capital diangkat ke permukaan, diperlihatkan kepada masyarakat yang sedang/sudah selesai berkonflik. Bahwa mereka memiliki unsur-unsur kedamaian yang sejatinya membuat kehidupan jadi lebih baik. Unsur-unsur positive capital di antaranya: optimisme untuk hidup lebih baik di masa depan, harapan akan kondisi hidup bermasyarakat yang damai, serta saling mengasihi satu sama lain sebagai sesama makhluk Tuhan. Selain itu peace narrative juga menggunakan bahasa yang "halus" dan menentramkan. Kata per kata yang dipilih merupakan kata yang mendorong pembaca atau pemirsa untuk bersimpati, berempati, dan berdamai.

Secara teknis peace narrative sebaiknya ditulis oleh wartawan yang memiliki ketaatan terhadap kode etik jurnalistik, serta setia kepada prinsipprinsip jurnalisme. Mengapa? Sebab peace narrative mengandaikan suatu kondisi ideal dimana wartawan mampu menulis berlandaskan hati nurani, serta tidak terkooptasi oleh kepentingankepentingan kelompok baik dari luar media maupun dari dalam media itu sendiri. Selain itu wartawan juga harus mampu mengumpulkan fakta-fakta baik di seputaran konflik. Artinya wartawan harus bisa mengangkat narasi yang bersifat positif, walaupun narasi tersebut tergolong narasi kecil. Misalnya saat konflik ada seorang wartawan yang berani menulis feature tentang peristiwa di mana seorang yang masuk dalam satu kelompok membantu orang dari kelompok lain. Padahal kedua kelompok tersebut sedang berkonflik. Tulisan itu pada masanya ibarat oase di tengah padang gurun. Ketika orang sedang berhadap-hadapan satu sama lain, serta berprasangka buruk satu sama lain, muncul sebuah tulisan di media yang memutarbalikkan logika konflik tersebut. Bahwa ada kebaikan di dalam kelompok orang yang dianggap musuh. Bahwa ada harapan akan hidup damai di masa mendatang. Bahwa prasangka dan stereotipe yang selama ini ada ternyata 
salah. Bahwa ada kebaikan dalam diri kelompok lain.

Tantangan terberat untuk melaksanakan peace narrative ini justru berasal dari dalam media, yakni kebijakan redaksi dan pemilik media. Sebab narasi damai bisa terpinggirkan ketika redaktur tidak menyetujui, atau ketika pemilik media memaksakan kecenderungan sikap medianya. Oleh karena itu dibutuhkan energi tinggi bagi wartawan yang akan melaksanakan peace narrative. Tidak hanya melulu tentang tulisannya, tetapi juga meyakinkan redaktur bahwa tulisannya penting untuk dimuat demi kondisi damai yang dicita-citakan bersama.

\section{III.B. Membentuk Media Center}

Saat berada dalam situasi konflik, media cenderung kesulitan mendapatkan informasi yang benar dan "bebas nilai". Besar kemungkinan data/fakta yang dijadikan dasar tulisan termasuk dalam kategori tidak valid, atau bahkan tidak benar. Penting kiranya bagi awak media untuk bersama-sama mendirikan media center. Media center berguna tidak hanya sebagai ruang untuk verifikasi data tetapi juga sebagai ruang penggodokan ideide damai. Oleh karena itu seyogyanya pendirian media center dilakukan dalam kerja sama dengan elemen-elemen civil society lainnya. Dengan demikian media menjadi partner bagi siapapun yang ingin mengusahakan komunitas damai. Jika perlu media center memberikan saluran khusus bagi elemen-elemen masyarakat yang ingin memberikan data/informasi yang akurat, juga bagi mereka yang ingin mengonfirmasi kebenaran suatu berita (yang telah dimuat oleh media sebelumnya).

\section{III.C. Meningkatkan Tingkatan Melek Literasi}

Di daerah konflik, informasi tertulis dari media dijadikan legitimasi kebenaran. Media dijadikan referensi utama oleh publik dalam mencari tahu informasi-informasi seputar konflik. Hal ini sungguh berbahaya sebab tidak semua media menyediakan informasi yang benar. Sebab sebagaimana dinyatakan Niklas Luhman (2000), kode kerja media bukan penyajian hal yang benar atau tidak benar, tetapi inform or not inform. Dalam konsep ini media tidak memiliki tanggungjawab langsung untuk menyajikan kebenaran. Hal yang disajikan media adalah informasi. Mengenai benar atau tidak maka publik harus melakukan cross check sendiri, mengonfirmasi berita yang ada, bahkan kalau perlu membandingkan berita dari satu media dengan media lainnya. Hal yang perlu diperhatikan juga adalah tidak semua media bekerja dengan dasar jurnalisme yang baik. Banyak media yang bekerja asal-asalan, pun ketika berada dalam situasi konflik.

Berangkat dari pemikiran tersebut, edukasi melek media/melek literasi penting dilakukan. Tujuannya untuk menciptakan daya kritis masyarakat terhadap media. Bahwa segala informasi yang disajikan media belum tentu benar. Kebenarannya harus dicek oleh masyarakat. Dengan demikian media berada dalam posisi yang lebih proporsional, tidak kemudian menjadi satu-satunya entitas yang menyajikan informasi yang (dianggap) benar.

Dari pengalaman yang ada, dalam konflik Maluku edukasi melek literasi dilakukan oleh elemen-elemen lintas agama. Dengan menggunakan pendekatan budaya, tokoh-tokoh agama 
menjumpai masyarakat dan memberikan penyadaran bahwa apa yang disajikan media belum tentu benar. Lebih baik masyarakat mengonfirmasi berita yang ada dengan bertanya langsung kepada aparat, atau kepada pihak-pihak yang netral (Baowollo, 2012). Awal mulanya terasa sulit, namun lama-kelamaan masyarakat semakin terbiasa dengan pemberitaan bombastis dari media. Bahwa mereka tidak akan mempercayai begitu saja informasi yang ada, melainkan terus-menerus bersikap kritis, taktis, dan strategis.

\section{Simpulan}

Situasi konflik adalah situasi yang tidak mudah bagi media. Ada media yang menyikapi situasi tersebut dengan menjual sensasi demi menaikkan ratingnya. Ada pula yang masuk dalam lingkaran konflik dengan membela kepentingan salah satu kelompok yang bertikai. Namun ada juga yang berusaha netral dan kritis terhadap konflik yang sedang berlangsung. Semua kembali kepada identitas media tersebut, apakah menjadi media partisan yang komersil atau menjadi media idealis yang membela kepentingan masyarakat banyak. Apapun pilihannya yang jelas media memiliki pengaruh besar dalam situasi konflik, baik yang menciptakan, memperluas, dan memperkeruh konflik atau sebaliknya menjadi bagian dari resolusi konflik.

Tawaran yang bisa diberikan untuk situasi tersebut adalah setia kepada jurnalisme. Jurnalisme adalah spirit media, roh bagi wartawan. Jurnalisme menjadi pencerah sekaligus panduan kerja wartawan dalam mencari, mengolah, dan menyajikan informasi kepada publik.
Bill Kovack dan Tom Rosenstiel (2003: 12) menyatakan tujuan utama jurnalisme adalah menyediakan informasi yang dibutuhkan warga agar mereka bisa hidup merdeka dan mengatur diri sendiri. Terdapat Sembilan elemen jurnalisme yang ditawarkan oleh Bill Kovack dan Tom Rosenstiel, yang dapat menjadi acuan kerja bagi awak media: mulai dari orientasi pada kebenaran, loyal kepada warga, disiplin verifikasi, independent terhadap sumber berita, memantau kekuasaan, menyediakan forum publik, menyajikan berita yang penting, menarik, dan relevan, hingga berita yang komprehensif dan proporsional. Serta terakhir, dan ini yang paling pokok, para praktisinya harus diperbolehkan mengikuti nurani mereka. Setia kepada prinsip-prinsip jurnalisme adalah pilihan tepat bagi media yang sedang berada dalam situasi konflik. Sehingga terdapat jaminan bahwa media dalam bekerja tidak akan berorientasi pada penghancuran masyarakat (lewat konflik yang terjadi), namun tetap berorientasi pada kondisi damai dan sejahtera yang memungkinkan warga masyarakat maju dan berkembang.

Pilihan untuk setia kepadajurnalisme ini juga berdampak positif bagi kondisi demokrasi, khusus di daerah yang terkena konflik. Demokrasi, khususnya demokrasi deliberatif, memungkinkan tiap warga mengemukakan pendapatnya mengenai hidup bersama, juga soal nilai-nilai yang perlu dijunjung tinggi, serta tidak ketinggalan pula ialah aturan perundang-undangannya. Hal ini sungguh sesuai dengan kaidah demokrasi deliberatif itu sendiri, sebagaimana dinyatakan oleh Budi Hardiman.

Apa itu demokrasi deliberatif?

Kata "deliberasi" berasal dari kata latin deliberatio yang artinya 
"konsultasi", "menimbangnimbang" atau "musyawarah". Demokrasi bersifat deliberatif, jika proses pemberian alasan atas suatu kandidat kebijakan publik diuji lebih dahulu lewat konsultasi publik atau lewat - dalam kosakata teoretis Habermas -“diskursus publik". Demokrasi deliberatif ingin meningkatkan intensitas partisipasi warga negara dalam pembentukan aspirasi dan opini (oefentlicher Meinungs-und Willensbildungsprozess) agar kebijakan-kebijakan dan undang-undang yang dihasilkan oleh pihak yang memerintah semakin mendekati harapan pihak yang diperintah (Hardiman 2004:18).

Kepentingan media untuk setia kepada jurnalisme sejalan dengan kepentingan demokrasi deliberatif, yakni munculnya ruang bagi warga untuk mengkritisi segala hal yang menjadi kepentingan bersama, termasuk keputusankeputusan pemerintah pada saat konflik.

\section{Daftar Pustaka}

Baowollo, Robert (2012). Wawancara Seputar Teori-Teori Konflik dan Penerapannya di Indonesia

Barash, David P. \& Charles P. Webel (2002). Peace and Conflict Studies. California: Sage Publications.

Baron, R.A. dan Byrne D. (1997). Social Psychology $8^{\text {th }}$. Ed. Massachusetts: Allyn \& Bacon

Burhanuddin, Yudhis M. (2008). Bali Yang Hilang: Pendatang, Islam, dan Etnisitas di Bali. Yogyakarta: Kanisius.

Eriyanto (2005). Koran, Bisnis, dan Perang dalam Jurnalisme Sastrawi, Antologi Liputan Mendalam dan Memikat. Harsono, Andreas \& Budi Setiyono. 2005. Jakarta: Pantau
Freedman, Des (2008). The Politics of Media Policy. Cambridge: Polity Press.

Hanitzsch, Thomas., Martin Loffelholz \& Ronny Mustamu (2004). Agents of Peace. Public Communication and Conflict Resolution in an Asian Setting. Frederich Ebert Stiftung

Hardiman, FB (2004), Demokrasi deliberatif: model untuk Indonesia pasca-Soeharto? Majalah Basis Nomor 11-12, Tahun ke 53, November-Desember 2004: 14 -31 .

Harsono, Andreas (2010). Agama Saya Adalah Jurnalisme. Yogyakarta: Kanisius

Inglis, Fred (1990). Media Theory An Introduction, Oxford: Basil Blackwell.

Kovach, Bill dan Tom Rosenstiel (2003). Sembilan Elemen Jurnalisme, Jakarta: Pantau.

Luhman, Niklas (2000). The Reality of The Mass Media. Cambridge: Polity Press

Meyer, Thomas With Lew Hinchman (2002). Media Democracy How the Media Colonize Politics, Cambridge: Polity Press.

Nugroho, Yanuar (2012). Memetakan Kebijakan Media di Indonesia, Jakarta: JIPG.

Nugroho, Yanuar (2012). Memetakan Lansekap Industri Media Kontemporer di Indonesia, Jakarta: JIPG.

Pruitt, Dean G. dan Jeffrey Z. Rubin (2004). Teori Konflik Sosial. Yogyakarta: Pustaka Pelajar

Rahabeat, Rudolf (2004). Politik Persaudaraan Membedah Peran Pers. Yogyakarta: Buku Baik

Rozi, Syafuan et.al. (2006). Kekerasan Komunal: Anatomi dan Resolusi Konflik di Indonesia. Yogyakarta: Pustaka Pelajar 
Sudibyo, Agus, Ibnu Hamad, dan Muhammad Qodari (2001). Kabarkabar Kebencian. Prasangka Agama di Media Massa. Jakarta: ISAI.

Toffler, Alvin (1987). Kejutan dan Gelombang. Jakarta: Panjta Simpati.
Watson, James (1996). Media Communication An Introduction to Theory and Process, London: Macmillan Press. 